\title{
Alterations in Cerebral Blood Flow and Phosphorylated Metabolites in Piglets during and after Partial Ischemia
}

\author{
ABBOT R. LAPTOOK, RONALD J. T. CORBETT, HUONG T. NGUYEN, JANET PETERSON, \\ AND RAY L. NUNNALLY \\ Biological Magnetic Resonance Center, Departments of Radiology [R.J.T.C., R.L.N.] and Pediatrics [A.R.L., \\ J.P.J, Southwestern Medical School, University of Texas Health Science Center at Dallas, Dallas, Texas 75235
}

\begin{abstract}
Ventilated piglets were studied before, during (15 min), and after $(90 \mathrm{~min})$ hemorrhagic hypotension to correlate a $60 \%$ reduction in cerebral blood flow with cerebral energy state using radiolabeled microspheres ( $n$ $=12$ ) and in vivo ${ }^{31} \mathrm{P}$ nuclear magnetic resonance spectroscopy $(n=11)$. Cerebral blood flow $\left(\mathrm{ml} \cdot \mathrm{min}^{-1} \cdot 100 \mathrm{~g}^{-1}\right)$ decreased during hypotension $(98 \pm 28$ to $41 \pm 28, p<$ $0.05)$, increased at $5 \mathrm{~min}$ postreperfusion $(131 \pm 53, p<$ $0.05)$, and returned to control values by $90 \mathrm{~min}$ postreperfusion. Cerebral $\mathrm{O}_{2}$ uptake was reduced during partial ischemia, remained depressed $5 \mathrm{~min}$ postreperfusion, and increased to within $20 \%$ of control values at 90 min postreperfusion. Relative to control, hypotension was associated with decreased $(p<0.05)$ phosphocreatine $(62 \pm$ $11 \%)$, phosphocreatine/inorganic phosphate ratio (41 \pm $10 \%)$, and nucleoside triphosphate $(82 \pm 12 \%)$ while inorganic phosphate increased $(155 \pm 32 \%, p<0.05)$. During ischemia intracellular $\mathrm{pH}$ dropped from $7.06 \pm 0.07$ to $6.59 \pm 0.31(p<0.05)$ and the cerebral arteriovenous difference of glucose increased. Phosphorylated metabolites returned to within $10 \%$ of control 15 min after blood reinfusion and remained constant thereafter. Based on calculations of ATP synthesis and utilization rates during control and hypotension, we speculate that the rate of energy utilization of the brain during ischemia is reduced $18-49 \%$ relative to the control utilization rate. (Pediatr Res 23: 206-211, 1988)
\end{abstract}

\section{Abbreviations}

MABP, mean arterial blood pressure

CBF, cerebral blood flow

${ }^{31} \mathrm{P}$ NMR, ${ }^{31}$ phosphorus nuclear magnetic resonance

$\mathrm{PCr}$, phosphocreatine

$\mathrm{Pi}$, inorganic phosphate

NTP, nucleoside triphosphate

pHa, arterial pH

pHpi, cerebral intracellular pH based on the chemical shift of $\mathbf{P i}$

pHet, cerebral intracellular $\mathrm{pH}$ based on the chemical shift of phosphomonoester

ANOVA, analysis of variance

Received July 24, 1987; accepted October 8, 1987.

Correspondence and reprint requests Abbot R. Laptook, Department of Pediatrics, University of Texas Health Science Center at Dallas, 5323 Harry Hines Boulevard, Dallas, TX 75235 .

Supported by USPHS Grant R23-NS22398 (A.R.L.) and NIH Southwest In Vivo Resource Facility Grant 5-P4I-RR02584 (R.L.N.). Postdoctoral support for R.J.T.C. was provided by the Department of Pediatrics UTHSCD and Medical Research Council (Canada).
Cerebral metabolic effects of partial ischemia are pertinent to multiple problems in sick human neonates. Events such as asphyxia, tension pneumothorax, intracranial hemorrhage, and hypovolemia may result in alterations in cerebral perfusion pressure with or without changes in blood $\mathrm{O}_{2}$ tension. Although scant data are available concerning CBF measurements in sick human neonates (1-4), partial cerebral ischemia may be of greater clinical concern than complete cerebral ischemia in view of the prevalence of events contributing to the former compared to the latter. Despite this, relatively little research has been done on perinatal brain ischemia and the most frequently used animal model has been complete cerebral ischemia via decapitation (57).

Inasmuch as partial ischemia encompasses a spectrum of cerebral perfusion pressure and $\mathrm{CBF}$, multiple investigations in adult animals have examined the reduction in $\mathrm{CBF}$ necessary to alter energy metabolism. Siesjo and Zwetnow (8) used hypovolemic hypotension in adult rats and reported unaltered brain ATP and PCr when MABP $>40 \mathrm{~mm} \mathrm{Hg}$. Although CBF was not measured, the results were attributed to maintenance of $\mathrm{CBF}$ at the lower limit of autoregulation. Similarly, reduction in cerebral perfusion pressure by increased CSF pressure was associated with unaltered adenine nucleotides until cerebral perfusion pressure $<30 \mathrm{~mm} \mathrm{Hg}$ (9). Further investigations of adult rats by Eklof and Siesjo (10) revealed that $50-60 \%$ decreases in CBF were necessary to decrease cerebral ATP. Welsh et al. (11) suggested that in adult animals there is a critical range of cerebral perfusion pressure at which CBF is sufficiently diminished and energy metabolism can no longer be maintained. Additional supportive evidence for this was provided by the observation that graded reductions of cerebral perfusion pressure from 60 to $30 \mathrm{~mm} \mathrm{Hg}$ in adult cats resulted in an increasing number of fluorescent patches of $\mathrm{NADH}$ within cerebral tissue with progressive alterations in ATP, PCr, and lactate concentration (12). Recently combined CBF and ${ }^{31} \mathrm{P}$ NMR measurements have established that the flow threshold for energy failure is in the range of 12$20 \mathrm{ml} \cdot \mathrm{min}^{-1} \cdot 100 \mathrm{~g}^{-1}$ in adult gerbils $(13,14)$.

Extrapolation from adult investigations to newborns is difficult because the neonatal period is characterized by lower cerebral $\mathrm{O}_{2}$ uptake (15), greater tolerance to hypoxia and ischemia (5), and enhanced transport of alternate cerebral energy substrates (16). We have demonstrated that piglets may serve as a model of partial cerebral ischemia in the neonatal period since a $60 \%$ fall in MABP is associated with a $50 \%$ reduction in CBF (17). We used this experimental model to determine if similar changes in $\mathrm{CBF}$ are associated with altered cerebral energy metabolites in the neonatal period. Cerebral energy metabolism was assessed in vivo using ${ }^{31} \mathrm{P}$ NMR spectroscopy to perform measurements in the same animal before, during, and after hypotension. 


\section{METHODS}

Twenty-six miniature swine were studied at $10 \pm 4$ (mean \pm SD) days of age after birth and weighed $1.76 \pm 0.42 \mathrm{~kg}$. Piglets remained with the sow until the morning of the study at which time one piglet was removed, premedicated with ketamine $(5$ $\mathrm{mg} / \mathrm{kg}$ intramuscularly), tracheotomized, and ventilated (Harvard Apparatus Rodent Respirator, model 680 ) with $70 \%$ nitrous oxide and $30 \% \mathrm{O}_{2}$. For blood flow determinations $(n=12)$ polyethylene catheters were placed in the left ventricle (via the left common carotid artery), abdominal aorta (via a femoral artery), inferior vena cava (via a femoral vein), left axillary artery, and the sagittal sinus after exposure of the midline calvarium and creation of a $1-\mathrm{cm}$ burr hole. For ${ }^{3 !} \mathrm{P}$ NMR measurements $(n=14)$ polyethylene catheters were placed in the left common carotid artery, abdominal aorta, and inferior vena cava. In five of the piglets used for ${ }^{31} \mathrm{P}$ NMR, a catheter was inserted into the sagittal sinus.

After catheter placement inspired gases were changed to $70 \%$ nitrogen and $30 \% \mathrm{O}_{2}, 0.3 \mathrm{mg} / \mathrm{kg}$ D-tubocurarine was administered intravenously, and a 90-min stabilization period commenced. Piglets used for ${ }^{31} \mathrm{P}$ NMR were wrapped in a heating pad (rectal temperature $38.5-39.5^{\circ} \mathrm{C}$ ), positioned supine with their heads resting on a single turn 4-cm diameter surface coil, and stabilized after placement within a superconducting magnet (1.89 Tesla, 30-cm bore diameter, Oxford Instruments), with vascular catheters routed outside the magnet. For this investigation the coil was applied to the intact scalp overlying both parietal and a portion of both frontal lobes of the brain. The contribution of skin to the in vivo spectrum was evaluated by examining the spatial variation in coil sensitivity as reported by Tofts et al. (18), determination of the total quantity of perchloric acid soluble phosphorus/gm of skin and cortical tissue, and analysis of NMR spectrum from skin biopsies obtained during normo- and hypotension. We calculate that $90 \%$ of the total phosphorus signal is derived from gray and white matter of the cerebral cortex underneath the coil and the remaining $10 \%$ from skin. During hypotension phosphorylated metabolites of skin do not undergo major changes in relative concentrations. Finally visual inspection of the tissue underneath the surface coil reveals the absence of muscle. We conclude that the contribution of skin and muscle to the evaluation of changes in brain phosphorylated metabolites is negligible.

Twenty-three piglets ( $n=12$ for microspheres, $n=11$ for NMR), underwent an experimental protocol consisting of three sequential study periods: control, hypotension, and postreperfusion. Hypotension was induced by withdrawing blood from the vena caval catheter into heparinized syringes until MABP $<45$ $\mathrm{mm} \mathrm{Hg}$, a pressure less than the lower limits of cerebral autoregulation (17). The mean estimated blood volume removed was $34 \pm 4 \mathrm{ml} / \mathrm{kg}$ and hypotension was maintained for $15 \mathrm{~min}$. Recirculation was achieved by reinfusion of all withdrawn blood over a 3 -min period and followed by a $90-\mathrm{min}$ postreperfusion period. Throughout the protocol the inspired $\mathrm{O}_{2}$ concentration was $30 \%$ and the ventilator rate was adjusted to maintain arterial isocapnia. In three additional piglets the effects of lengthening the duration of hypotension was evaluated. Hemorrhagic hypotension was used to maintain a reduced MABP for $35 \mathrm{~min}$ and NMR data are reported for spectrum obtained in the last $8 \mathrm{~min}$ of this interval. Recovery was not studied in these three animals.

CBF was determined during control, the last $3 \mathrm{~min}$ of hypotension, and 5 and $90 \mathrm{~min}$ after the onset of reperfusion. Before $\mathrm{CBF}$ measurements blood was sampled for cerebral arteriovenous differences of $\mathrm{O}_{2}$ content, blood gases, and $\mathrm{pH}$ (total volume of blood removed at each CBF determination was $5.4 \mathrm{ml}$ ). Blood loss was immediately replaced using sterile packed red blood cells previously obtained from a littermate and stored in acidcitrate-dextrose anticoagulant. For piglets studied by ${ }^{31} \mathrm{P}$ NMR, spectrum were obtained during the control period, the last $8 \mathrm{~min}$ of hypotension, and 11 times sequentially postreperfusion commencing after reinfusion of withdrawn blood. All animals studied by ${ }^{31} \mathrm{P}-\mathrm{NMR}$ were sampled for arterial blood gases and $\mathrm{pH}$ at the midpoint of spectrum collected during control, hypotension, and at 5,30,60, and 90 min postreperfusion. In five piglets cerebral arteriovenous differences of $\mathrm{O}_{2}$ content and plasma concentrations of glucose and lactic acid were determined using the catheter in the sagittal sinus to collect cerebral venous blood. The total volume of blood removed for cerebral arteriovenous difference samples was $2 \mathrm{ml}$ and each piglet's own packed red blood cells were reinfused after removal of plasma for glucose and lactic acid concentrations.

Vascular pressures, blood gases, $\mathrm{pH}$, and $\mathrm{O}_{2}$ content were measured as previously described (17). Lactic acid concentrations were determined using a lactate dehydrogenase enzymatic assay (Sigma Chemical Co) on plasma $(200 \mu \mathrm{l})$ after deproteinization with $8 \%$ perchloric acid. Glucose determinations were performed on plasma $(50 \mu \mathrm{l})$ after deproteinization with $2 \%$ perchloric acid using a glucose-oxidase enzymatic method (Sigma). CBF was measured using the reference organ radiolabeled microsphere technique as described by Heymann et al. (19). For each measurement approximately $8 \times 10^{5}$ microspheres suspended in 3.5 $\mathrm{ml}$ of dextran were injected into the left ventricle over a $30-\mathrm{s}$ period after which the catheter was flushed with $1.2 \mathrm{ml}$ of isotonic saline. Starting before the microsphere injection arterial reference samples were withdrawn from the axillary artery and abdominal aortic catheters into counting vials under oil at a rate of $1.03 \mathrm{ml} /$ min for 2 min with a Harvard pump. All brain tissue and reference samples contained more than 400 microspheres.

At study completion the piglets were sacrificed (Nembutal, $150 \mathrm{mg} / \mathrm{kg}$ intravenously, Abbot Laboratories) and catheter placement verified. For piglets injected with microspheres the entire brain was removed, cut into sections, and the weight of each section determined. All brain tissue and blood reference samples were counted in a Packard 3-Channel Auto-Gamma Spectrometer (model 5385) and CBF computed as previously described (19). Wet tissue weight was used to express blood flow as $\mathrm{ml} \cdot \mathrm{min}^{-1} \cdot 100 \mathrm{~g}^{-1}$.

Calculated variables included cerebral $\mathrm{O}_{2}$ delivery, $\mathrm{O}_{2}$ uptake, and $\mathrm{O}_{2}$ extraction. Cerebral $\mathrm{O}_{2}$ delivery $\left(\mathrm{mmol} \cdot \mathrm{min}^{-1} \cdot 100 \mathrm{~g}^{-1}\right.$ ) is derived from the product of $\mathrm{CBF}$ and arterial $\mathrm{O}_{2}$ content. By the Fick principle, cerebral $\mathrm{O}_{2}$ uptake $\left(\mathrm{mmol} \cdot \mathrm{min}^{-1} \cdot 100 \mathrm{~g}^{-1}\right)$ is equivalent to the product of $\mathrm{CBF}$ and the cerebral arteriovenous difference of $\mathrm{O}_{2}$ content. Cerebral $\mathrm{O}_{2}$ extraction is calculated from the ratio of cerebral $\mathrm{O}_{2}$ uptake/cerebral $\mathrm{O}_{2}$ delivery.

In vivo ${ }^{31} \mathrm{P}$ NMR data were collected on a Nicolet NT-80 NMR spectrometer. After shimming on the proton signal from the brain, phosphorus spectrum were obtained using an observe frequency of $32.5 \mathrm{MHz}$, a $50-\mu \mathrm{s}$ excitation pulse length, and a 3.4-s recycle time. Each NMR spectrum had 4096 data points and 140 transients were averaged (approximately $8 \mathrm{~min} / \mathrm{spec}-$ trum). An external standard, methylene diphosphonate $(20 \mathrm{mM})$, was used in each study as a chemical shift reference. Quantitation of ${ }^{31} \mathrm{P}$ NMR was based on peak heights, normalized to the external standard, and corrected for partial saturation by comparison to spectrum collected using a 20 -s recycle time. Spectral analysis over the course of a study compared normalized peak heights during hypotension and postreperfusion to values at control and results were expressed as percent of control. Intracellular pH was calculated from the chemical shift of the phosphomonoester ( $\mathrm{pHet}$ ) or Pi peak (pHpi). Appropriate titration curves were used to formulate the following equations from which intracellular $\mathrm{pH}$ was calculated (20):

$$
\begin{aligned}
& \mathrm{pHpi}=6.757+\log 10((\mathrm{x}-3.282) /(5.698-\mathrm{x}) \\
& \mathrm{pHet}=5.625+\log 10((\mathrm{y}-3.190) /(6.946-\mathrm{y})
\end{aligned}
$$

were $\mathrm{x}$ and $\mathrm{y}$ refer to the chemical shift of $\mathrm{Pi}$ and phosphomonoester peak, respectively. Results were analyzed with a one-way ANOVA with repeated measures and regression analysis. Significant interactions on the ANOVA $(p<0.05)$ were localized by 
a Newman-Keuls multiple comparison test. Values reported are the mean and SD.

\section{RESULTS}

Analysis of arterial and cerebral venous pressure, $\mathrm{pH}$, and blood gases from piglets used for blood flow determinations and ${ }^{31} \mathrm{P}$ NMR were similar and hence results for the 23 animals were pooled (Fig. 1). Arterial hypotension was associated with alterations in cerebral venous pressure, arterial and cerebral venous $\mathrm{pH}$, and cerebral venous blood gases. Cerebral venous $\mathrm{O}_{2}$ tension decreased during hypotension from $32 \pm 7$ to $19 \pm 6 \mathrm{~mm} \mathrm{Hg}$, increased at 5 -min postreperfusion $(63 \pm 16 \mathrm{~mm} \mathrm{Hg})$ and returned to control values by 30 -min postreperfusion. Arterial $\mathrm{PCO}_{2}$ decreased to $28 \pm 9 \mathrm{~mm} \mathrm{Hg}$ during hypotension and was associated with an elevation in cerebral venous $\mathrm{CO}_{2}$ tension. By 90-min postreperfusion all physiologic variables had returned to control levels.

During hypotension CBF fell $56 \pm 31 \%$ then rose $33 \pm 30 \%$ above control at 5 -min postreperfusion, and returned to preischemic levels at $90 \mathrm{~min}$ postreperfusion (Table 1). The fall in $\mathrm{CBF}$ contributed to disproportionate reductions in cerebral $\mathrm{O}_{2}$

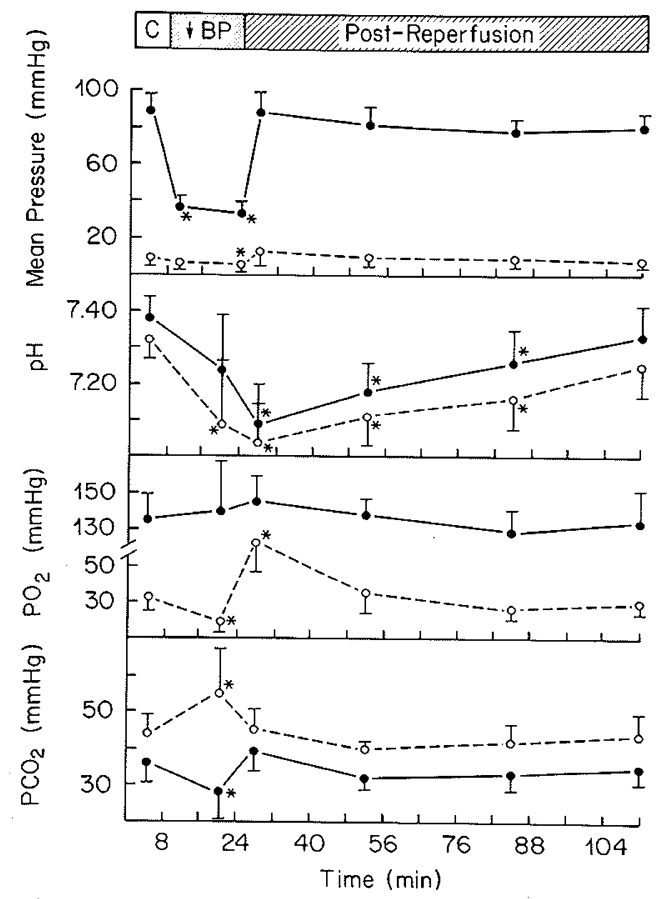

Fig. 1. The effect of hypotension on arterial (-_- and cerebral venous $(\mathrm{O}---\mathrm{O})$ pressure, $\mathrm{pH}, \mathrm{PO}_{2}$, and $\mathrm{PCO}_{2}$. Data are mean $\pm \mathrm{SD}$ of 23 piglets studied with either microspheres or ${ }^{31} \mathrm{P}$ NMR during control $(c)$, hypotension $(B P)$, and postreperfusion. ${ }^{*} p<0.05$ versus control.
CBF contributed to disproportionate reductions in cerebral $\mathrm{O}_{2}$ delivery and $\mathrm{O}_{2}$ uptake so that cerebral fractional extraction of $\mathrm{O}_{2}$ rose. The increase of $\mathrm{CBF}$ and arterial $\mathrm{O}_{2}$ content 5-min postreperfusion caused cerebral $\mathrm{O}_{2}$ delivery to return to preischemic values, but $\mathrm{O}_{2}$ uptake remained decreased and gave rise to a low cerebral fractional extraction of $\mathrm{O}_{2}$ and the previously noted cerebral venous hyperoxia. At 90 -min postreperfusion cerebral $\mathrm{O}_{2}$ delivery again decreased reflecting a reduced arterial $\mathrm{O}_{2}$ content (due to a lowered hematocrit) and not an alteration of $\mathrm{CBF}$. Cerebral $\mathrm{O}_{2}$ uptake was $20 \%$ below control levels and cerebral fractional $\mathrm{O}_{2}$ extraction was comparable to control.

In piglets used for ${ }^{31} \mathrm{P}$ NMR studies arteriál and cerebral venous plasma glucose concentrations (Table 2) rose during hypotension. For the five animals with a sagittal sinus catheter, the cerebral arteriovenous difference of glucose widened from control to hypotension, $0.4 \pm 0.01$ to $4.0 \pm 2.7 \mathrm{mmol} / \mathrm{liter}$, respectively $(p<0.05)$. Elevations of arterial plasma lactic acid concentration occurred concurrent with decreased pHa. Cerebral arteriovenous differences of lactic acid concentration were negligible at control $(0.0 \pm 0.10 \mathrm{mmol} / \mathrm{liter})$ and subsequent arteriovenous differences did not change.

Figure 2 displays representative ${ }^{31} \mathrm{P}$ NMR spectrum from a piglet during control, hypotension, and postreperfusion. Seven resonance peaks are detectable and include the $\beta, \alpha$, and $\gamma$ peaks of NTP, PCr, phosphodiester, Pi, and phosphomonoester. The peak height ratio of $\mathrm{PCr} / \mathrm{Pi}$ at control for 11 piglets was $2.0 \pm$ 0.6 . Changes during hypotension included an increase in $\mathrm{Pi}$ and a decrease in $\mathrm{PCr}$, pHpi, and $\mathrm{PCr} / \mathrm{Pi}(0.8 \pm 0.3$ for the latter, $n$ $=11, p<0.05$ ). Within $16-24 \mathrm{~min}$ of reinfusion the ${ }^{31} \mathrm{P}$ NMR spectrum is not different than control.

In Figure $3 \mathrm{pHpi}$ and percent changes in $\mathrm{PCr}, \mathrm{Pi}$, and NTP are plotted versus time. The pHpi was $7.06 \pm 0.07$ at control, decreased to $6.59 \pm 0.31$ during hypotension, and remained at a

Table 1. Effect of hypotension on $\mathrm{CBF}, \mathrm{O}_{2}$ delivery, $\mathrm{O}_{2}$ uptake, and fractional extraction of $\mathrm{O}_{2}$ in piglets studied with microspheres (mean $\pm S D$ )

\begin{tabular}{|c|c|c|c|c|}
\hline & \multirow[b]{2}{*}{ Control } & \multirow[b]{2}{*}{ Hypotension } & \multicolumn{2}{|c|}{ Postreperfusion } \\
\hline & & & $5 \mathrm{~min}$ & $90 \mathrm{~min}$ \\
\hline $\begin{array}{l}\mathrm{CBF}(\mathrm{ml} \cdot \\
\min ^{-1} \cdot 100 \\
\left.\mathrm{~g}^{-1}\right)\end{array}$ & $98 \pm 27$ & $41 \pm 27^{*}$ & $131 \pm 53^{*}$ & $83 \pm 37$ \\
\hline $\begin{array}{l}\mathrm{O}_{2} \text { delivery } \\
\text { (mmol. } \\
\mathrm{min}^{-1} \cdot 100 \\
\mathrm{~g}^{-1} \text { ) }\end{array}$ & $0.44 \pm 0.07$ & $0.15 \pm 0.12^{*}$ & $0.48 \pm 0.13$ & $0.33 \pm 0.11$ \\
\hline $\begin{array}{l}\mathrm{O}_{2} \text { uptake } \\
\text { (mmol. } \\
\min ^{-1} \cdot 100 \\
\left.\mathrm{~g}^{-1}\right)\end{array}$ & $0.26 \pm 0.05$ & $0.12 \pm 0.08^{*}$ & $0.13 \pm 0.04^{*}$ & $0.21 \pm 0.06^{*}$ \\
\hline $\mathrm{O}_{2}$ extraction & $0.59 \pm 0.11$ & $0.86 \pm 0.08^{*}$ & $0.30 \pm 0.10^{*}$ & $0.65 \pm 0.10$ \\
\hline
\end{tabular}

Table 2. Effect of hypotension on arterial (a) and cerebral arteriovenous differences (av) of plasma concentrations of glucose and lactic acid in piglets studied with ${ }^{31} P$ NMR (mean $\left.\pm S D\right)$

\begin{tabular}{|c|c|c|c|c|c|c|}
\hline & \multirow[b]{2}{*}{ Control } & \multirow[b]{2}{*}{ Hypotension } & \multicolumn{4}{|c|}{ Postreperfusion } \\
\hline & & & $5 \mathrm{~min}$ & $30 \mathrm{~min}$ & $60 \mathrm{~min}$ & $90 \mathrm{~min}$ \\
\hline $\begin{array}{l}\text { Glucose (a) (mmol/li- } \\
\text { ter, } n=5)\end{array}$ & $7.2 \pm 0.6$ & $14.8 \pm 5.7^{*}$ & $12.0 \pm 4.0^{*}$ & $10.9 \pm 3.6$ & $9.9 \pm 3.5$ & $8.6 \pm 2.4$ \\
\hline $\begin{array}{l}\text { Glucose (av) (mmol/li- } \\
\text { ter, } n=5)\end{array}$ & $0.4 \pm 0.1$ & $4.0 \pm 2.7^{*}$ & $0.6 \pm 0.4$ & $0.2 \pm 0.1$ & $0.7 \pm 0.5$ & $0.6 \pm 0.4$ \\
\hline $\begin{array}{l}\text { Lactic acid (a) (mmol/ } \\
\quad \text { liter, } n=5)\end{array}$ & $1.4 \pm 0.6$ & $10.7 \pm 1.8^{*}$ & $10.1 \pm 0.8^{*}$ & $8.3 \pm 1.5^{*}$ & $7.0 \pm 2.3^{*}$ & $5.6 \pm 2.7^{*}$ \\
\hline $\begin{array}{l}\text { Lactic acid (av) } \\
\qquad(\mathrm{mmol} / \mathrm{liter}, n=5)\end{array}$ & $0.0 \pm 0.1$ & $-0.1 \pm 0.2$ & $0.1 \pm .3$ & $0.1 \pm 0.3$ & $0.1 \pm 0.1$ & $0.0 \pm 0.2$ \\
\hline
\end{tabular}



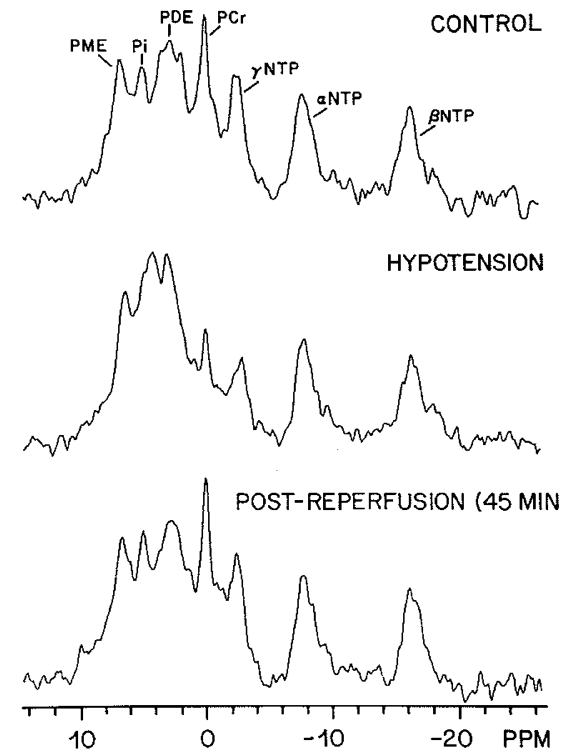

Fig. 2. Representative ${ }^{31} \mathrm{P}$ NMR spectrum of a piglet during control (top), hypotension (middle), and 45 min postreperfusion (bottom). Resonance peaks are labeled as follows: $\beta, \alpha, \gamma$, NTP- $\beta, \alpha$, and $\gamma$ peaks of nucleoside triphosphate, $\mathrm{PCr}$, phosphodiester $(P D E), \mathrm{Pi}$, and phosphomonoester $(P M E)$.

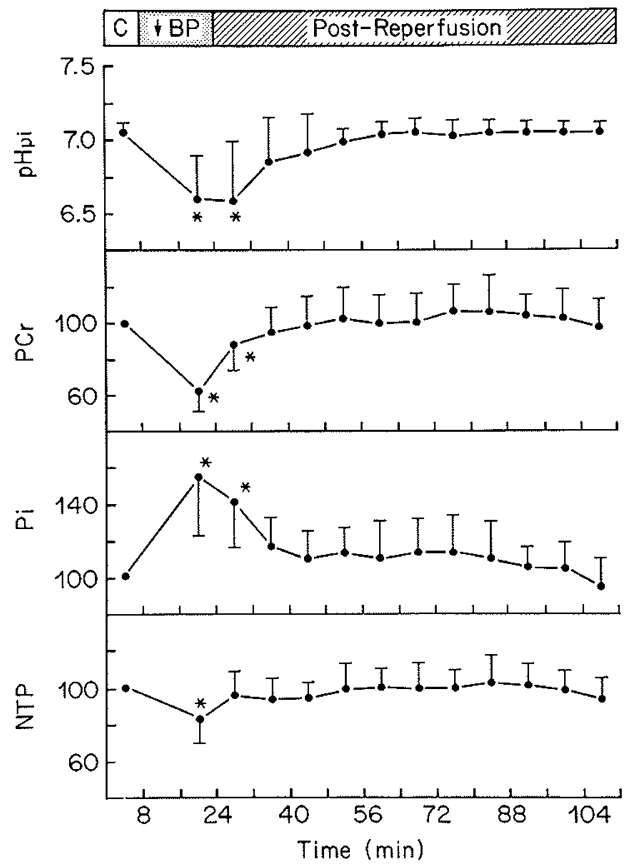

Fig. 3. Changes in pHpi and relative concentrations of $\mathrm{PCr}, \mathrm{Pi}$, and nucleoside triphosphate $(N T P)$ before, during, and after hypotension. Data are mean \pm SD and the phosphorylated metabolites are represented as the percent change relative to control. NTP represents the mean of the $\beta, \alpha$, and $\gamma$ peaks. ${ }^{*} p<0.05$ compared to control.

similar value of $6.58 \pm 0.44$, during the first spectrum $(0-8 \mathrm{~min})$ after blood reinfusion. Subsequently there was rapid recovery of $\mathrm{pHpi}$ to control values. Intracellular pHet calculated from the chemical shift of the phosphomonoester peak revealed quantitatively similar changes between control and hypotension with a $\Delta$ pHet of $-0.39 \pm 0.24$. PCr fell to $62 \pm 11 \%$ of control during hypotension and within $8 \mathrm{~min}$ of blood reinfusion $\mathrm{PCr}$ increased to $88 \pm 14 \%$ of control. In all subsequent spectrum $\mathrm{PCr}$ returned to control values. Pi increased during hypotension to $155 \pm 32 \%$ and remained elevated $(141 \pm 26 \%) 8 \mathrm{~min}$ after blood reinfusion.

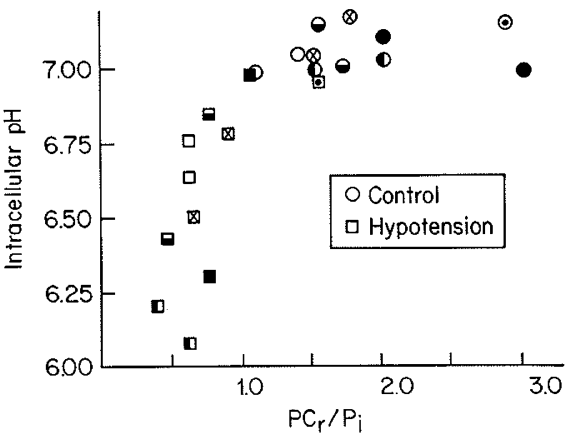

Fig. 4. Relationship between pHpi and the $\mathrm{PCr} / \mathrm{Pi}$ ratio during control and hypotension. Littermates are designated by similar symbols.

In subsequent spectrum Pi returned to control values. During hypotension less prominent changes occurred in NTP $(82 \pm 12 \%$ of control) and was rapidly restored to baseline values after blood reinfusion. In Figure $4 \mathrm{pHpi}$ is plotted versus $\mathrm{PCr} / \mathrm{Pi}$ for data collected during control and hypotension. The relationship is nonlinear with a steep decline in $\mathrm{pHpi}$ when $\mathrm{PCr} / \mathrm{Pi}$ is less than 1. The $\mathrm{PCr} / \mathrm{Pi}$ ratio for individual piglets during control correlated well with their subsequent $\mathrm{PCr} / \mathrm{Pi}$ during hypotension $(r=$ $0.83, p<0.01)$, but did not correlate well with either $\mathrm{pHpi}$ or percent reduction in NTP during hypotension $(r=0.39$ and 0.50 , respectively).

In three additional piglets the duration of hypotension was increased to 35 min with a decrease in MABP from $76 \pm 5$ to $28 \pm 5 \mathrm{~mm} \mathrm{Hg} .{ }^{31} \mathrm{P}$ NMR spectrum obtained during the last 8 min of this interval revealed reductions in $\mathrm{PCr}(40 \pm 20 \%$ of control), NTP $(53 \pm 17 \%$ of control), $\mathrm{pHpi}(7.05 \pm 0.04$ to 6.16 $\pm 0.12)$, and increases in $\mathrm{Pi}(262 \pm 105 \%$ above control).

\section{DISCUSSION}

In preterm and term human neonates positron-emission tomography and xenon clearance have provided preliminary $\mathrm{CBF}$ data implicating an important role for ischemia after intraventricular hemorrhage (1) and asphyxia $(2,3)$. Limitations of current methodology, such as spatial resolution, prevent accurate distinction of cerebral tissue subjected to complete or incomplete ischemia. Despite the apparent importance of cerebral ischemia in neonatal disease, few animal investigations have examined both cerebral vascular and metabolic effects of ischemia and of those performed most have used in vitro freeze clamp techniques in newborn rats and mice to assess complete ischemia (5-7). Norwood et al. (21) studied complete cerebral ischemia in vivo using isolated perfused neonatal rat brain and ${ }^{31} \mathrm{P}$ NMR. To our knowledge brain energy metabolism during partial ischemia and the postischemic interval have not been investigated in an intact newborn animal using noninvasive methodology. ${ }^{31} \mathrm{P}$ NMR offers the ability to monitor in vivo cerebral phosphorylated metabolites over time, permitting measurements to be acquired before, during, and after ischemia in individual animals. The use of different animals for separate study time points and potential alterations induced by brain freezing for in vitro analysis are obviated.

The results of our investigation demonstrate that a $50-60 \%$ reduction in CBF is associated with reversible perturbations of cerebral $\mathrm{O}_{2}$ uptake, high energy phosphorylated metabolites, and intracellular $\mathrm{pH}$. As indicated by the three piglets studied for 35 min of hypotension, if the duration of partial ischemia is prolonged, progressively larger alterations in cerebral phosphorylated metabolites are observed. Thus, an absolute CBF of approximately $40 \mathrm{ml} \cdot \mathrm{min}^{-1} \cdot 100 \mathrm{~g}^{-1}$ was associated with failure to maintain control levels of cerebral high energy metabolites. This $\mathrm{CBF}$ is higher than the critical flow threshold for energy failure in adult animals of other species such as gerbils $(13,14)$. When 
expressed as a relative reduction in CBF, energy failure in piglets occurs at similar flow decrements as in adult rats (10) and gerbils (14). However, our data do not allow us to draw conclusions concerning differences in ischemic threshold between newborn and adult animals because we did not study adult miniature swine and we did not examine a spectrum of CBF reduction to accurately identify a threshold for energy failure.

Based on biochemical analysis of extracts from brain frozen in situ, complete ischemia in newborn and adult animals impairs oxidative phosphorylation and results in reduced high energy phosphorylated metabolites $(5-7,22-24)$. The reduction in cerebral $\mathrm{O}_{2}$ uptake herein is consistent with a decrease in cerebral oxidative metabolism. The results of the ${ }^{31} \mathrm{P}$ NMR experiments directly support the contention that a $50-60 \%$ decrease in $\mathrm{CBF}$ perturbs energy metabolism because an increase in Pi and reductions in PCr, NTP, and pHpi were observed. The reduction in $\mathrm{pHpi}$, NTP, and the increase in cerebral arteriovenous difference of glucose are consistent with a change in cellular metabolism to a combination of aerobic plus anaerobic energy production during partial ischemia. Interestingly, the fall in pHpi was of similar magnitude to estimates made for complete ischemia models $(21,25)$. For piglets subjected to longer intervals of partial ischemia further decreases in $\mathrm{pHpi}$ occurred, reflecting continued substrate delivery, and glycolysis, thus contributing to higher tissue lactate concentrations $(26,27)$.

The $20 \%$ fall in NTP in piglets must be interpreted cautiously in view of potential regional variations in brain metabolism. Welsh et al. (11) reported a regional evaluation of cerebral ATP concentrations during ischemia revealing few values between 30 and $80 \%$ of control ATP. Thus, a $20 \%$ reduction in ATP may correspond to $80 \%$ of subregions with normal ATP and $20 \%$ with total depletion of ATP. Welsh et al. (11) speculated that an apparent threshold for ATP concentrations during ischemia reflects rapid energy utilization relative to low energy reserves.

However, Welsh et al. (11) also noted that energy utilization may be altered during ischemia as evidenced by changes in electroencephalographic activity. We have used our results to estimate brain energy utilization during ischemia. The cerebral $\mathrm{O}_{2}$ uptake at control, $2.6 \mu \mathrm{mol} \cdot \mathrm{min}^{-1} \cdot \mathrm{g}^{-1}$ (Table 1), is sufficient to metabolize the entire cerebral glucose uptake $(0.39 \mu \mathrm{mol}$. $\min ^{-1} \cdot \mathrm{g}^{-1}$ calculated from control data in Tables 1 and 2) by oxidative phosphorylation. This gives a maximal ATP production rate of $14 \mu \mathrm{mol} \cdot \mathrm{min}^{-1} \cdot \mathrm{g}^{-1}$ at control. Inasmuch as ATP levels at control are constant, ATP production and utilization must be equivalent. During hypotension cerebral $\mathrm{O}_{2}$ uptake is decreased to $1.2 \mu \mathrm{mol} \cdot \mathrm{min}^{-1} \cdot \mathrm{g}^{-1}$ and is sufficient for $7.2 \mu \mathrm{mol}$. $\mathrm{min}^{-1} \cdot \mathrm{g}^{-1}$ of ATP production provided that a cerebral glucose uptake of at least $0.2 \mu \mathrm{mol} \cdot \mathrm{min}^{-1} \cdot \mathrm{g}^{-1}$ is attained. From the CBF and arteriovenous difference during hypotension we calculate a cerebral glucose uptake of $1.6 \mu \mathrm{mol} \cdot \mathrm{min}^{-1} \cdot \mathrm{g}^{-1}$, in excess of the above requirement. Even if all the remaining glucose was metabolized by anaerobic glycolysis, we estimate a maximal ATP production rate of $10 \mu \mathrm{mol} \cdot \mathrm{min}^{-1} \cdot \mathrm{g}^{-1}$. If the rate of ATP utilization during hypotension remained the same as the control rate, then total depletion of high energy metabolites would occur within 1 to $5 \mathrm{~min}$, depending on the production rate $(7.2-10$ $\mu \mathrm{mol} \cdot \mathrm{min}^{-1} \cdot \mathrm{g}^{-1}$ ) and available brain energy reserves (6 to 20 $\mu \mathrm{mol} / \mathrm{g}$ ) assumed (5).

The above calculated time for total energy depletion does not agree with the observed 20 and $38 \%$ reductions in ATP and PCr levels, respectively, after $15 \mathrm{~min}$ of hypotension. To account for the observed drops in brain high energy metabolites, brain energy utilization may be only fractionally $(1-15 \%)$ greater than production. Thus, if our estimated rate of ATP production is correct $\left(7.2-10 \mu \mathrm{mol} \cdot \mathrm{min}^{-1} \cdot \mathrm{g}^{-1}\right)$, then the rate of energy utilization during hypotension would be reduced by at least $18-49 \%$ compared to control energy utilization. We point out two important limitations that make these estimates speculative: 1) use of the Fick principle to accurately calculate substrate utilization requires a steady state of blood flow, arteriovenous differences, and tissue metabolism (28) and this may not be the case during ischemia and 2) NMR measurements derive a signal from a localized region of tissue which may not be representative of the bulk tissue giving rise to $\mathrm{CBF}$ and arteriovenous difference measures.

Reinfusion of blood was followed by reestablishment of control levels of cerebral phosphorylated metabolites and pHpi. Even after profound partial or complete cerebral ischemia, restoration of PCr and ATP to within $80 \%$ of control values have been reported $(29,30)$. The changes in cerebral phosphorylated metabolites paralleled an increase in cerebral $\mathrm{O}_{2}$ delivery although cerebral $\mathrm{O}_{2}$ uptake and cerebral fractional extraction of $\mathrm{O}_{2}$ remained low. This observation allows for alternative speculations such as: 1) further reductions in brain energy requirements after reperfusion, 2) continued energy production from anaerobic metabolism, or 3) the occurrence of an elevated cerebral $\mathrm{O}_{2}$ uptake in the first minutes after ischemia providing sufficient $\mathrm{O}_{2}$ to restore high energy metabolites followed by a fall in $\mathrm{O}_{2}$ uptake at the time of our measurements. Steen et al. (31) reported observations in adult dogs to support this.

It has been suggested that $\mathrm{PCr} / \mathrm{Pi}$ represents a bioenergetic reserve of tissue because $\mathrm{PCr}$ helps maintain ATP concentrations as the latter is converted to ADP and Pi during hypoxia (32). The decrease in $\mathrm{PCr}$ and increase in Pi with small reductions in NTP during ischemia (Fig. 3) supports this concept. As noted by others (25), a pool of $\mathrm{PCr}$ persists when ATP decreased during ischemia, suggesting compartmentation of $\mathrm{PCr}$ in the brain as speculated for muscle (33). Alternative explanations include differential rates of fall of $\mathrm{PCr}$ and ATP during intracellular acidosis (25) or creatine phosphokinase inhibition secondary to brain ischemia. Herein the $\mathrm{PCr} / \mathrm{Pi}$ ratio at control $(2.0 \pm 0.6)$ agrees with preliminary data by Delivoria-Papadopoulos et al. (34) of a PCr/Pi ratio of 1.7 in piglets. Similar PCr/Pi ratios have been reported for 10- to 16-day-old rabbits (2.3) and neonatal lambs $(1.4)(35,36)$. Considerable variation existed among piglets for the control $\mathrm{PCr} / \mathrm{Pi}$ ratios but within a litter values tend to cluster (Fig. 4). Hilberman et al. (37) reported that in adult dog brain a $\mathrm{PCr} / \mathrm{Pi}$ of 1.0 represents a critical value and when less than one profound metabolic alterations occurred. The results in Figure 4 are consistent with this; however, when $\mathrm{PCr} / \mathrm{Pi}<1$ the magnitude of change in $\mathrm{pHpi}$ varied at a given $\mathrm{PCr} / \mathrm{Pi}$. Although $\mathrm{PCr} / \mathrm{Pi}$ may represent one bioenergetic reserve, we were unable to use the control PCr/Pi to predict the extent of alterations in cerebral phosphorylated metabolites and $\mathrm{pHpi}$ during partial ischemia for individual animals.

The results of this investigation demonstrate that changes in cerebral phosphorylated energy metabolites occur at a CBF of $40 \mathrm{ml} \cdot \mathrm{min}^{-1} \cdot 100 \mathrm{~g}^{-1}$ which represents a $56 \%$ reduction of CBF relative to control. The alterations in cerebral energy metabolism were reversible as demonstrated by serial ${ }^{31} \mathrm{P}$ NMR measurements. Combined CBF and ${ }^{31} \mathrm{P}$ NMR measurements should be useful in further defining ischemic thresholds for irreversible energy failure.

Acknowledgment. The authors thank Ms. Marilyn Dixon for preparation of the manuscript.

\section{REFERENCES}

1. Volpe JJ, Herscovitch P, Perlman JM, Raichle ME 1983 Positron emission tomography in the newborn: extensive impairment of regional cerebral blood flow with intraventricular hemorrhage and hemorrhagic intracerebral involvement. Pediatrics 72:589-601

2. Volpe JJ, Herscovitch P, Perlman J, Kreusser KL, Raichle ME 1985 Positron emission tomography in the asphyxiated term newborn: parasagittal impairment of cerebral blood flow. Ann Neurol 17:287-296

3. Lou HC, Lassen NA, Friis-Hansen B 1979 Impaired autoregulation of cerebral blood flow in the distressed newborn. J Pediatr 94:118-121

4. Milligan DWA 1980 Failure of autoregulation and intraventricular hemorrhage in preterm infants. Lancet 1:896-898

5. Lowry OH, Passonneau JV, Hasselberger FX, Schulz DW 1964 Effect of ischemia on known substrates and cofactors of the glycolytic pathway in 
brain. J Biol Chem 239:18-30

6. Thurston $\mathrm{JH}, \mathrm{McD}$ ougal DB 1969 Effect of ischemia on metabolism of the brain of the newborn mouse. Am J Physiol 216:348-352

7. Duffy TE, Kohle SJ, Vannucci RC 1975 Carbohydrate and energy metabolism in perinatal rat brain: Relation to survival in anoxia. $J$ Neurochem $24: 271-$ 276

8. Siesjo BK, Zwetnow NN 1970 The effect of hypovolemic hypotension on extra and intracellular acid-base parameters and energy metabolites in the rat brain. Acta Physiol Scand 79:114-124

9. Siesjo BK, Swetnow NN 1970 Effects of increased cerebrospinal fluid pressure upon adenine nucleotides and upon lactate and pyruvate in rat brain tissue. Acta Neurol Scand 46:187-202

10. Eklof B, Siesjo BK 1972 The effect of bilateral carotid artery ligation upon the blood flow and the energy state of the rat brain. Acta Physiol Scand 86:155165

11. Welsh FA, Durity F, Langfitt TW 1977 The appearance of regional variations in metabolism at a critical level of diffuse cerebral oligemia. J Neurochem 28:71-79

12. Welsh FA, O'Connor MJ, Marey VR 1978 Effect of oligemia on regional metabolite levels in cat brain. J Neurochem 31:311-319

13. Naritomi H, Sasaki M, Kanashiro M, Sawada T, Niimi T 1987 Cerebral blood flow thresholds for energy disturbance and ion pump failure studied by in vivo ${ }^{31} \mathrm{P}$ and ${ }^{23} \mathrm{Na}$ nuclear magnetic resonance spectroscopy. J Cereb Blood Flow Metab 1(suppl):S96

14. Crockard HA, Gadian DG, Frackowiak RSJ, Proctor E, Allen K, Williams SR, Russell RWR 1987 Acute cerebral ischemia: Concurrent changes in cerebral blood flow, energy metabolites, $\mathrm{pH}$ and lactate measured with hydrogen clearance and $\mathrm{P}-31$ and $\mathrm{H}-1$ nuclear magnetic resonance spectroscopy. II. Changes during ischemia. J Cereb Blood Flow Metab 7:394-402

15. Vannucci RC, Hernandez MJ 1980 Perinatal cerebral blood flow. In: Perinatal Brain Insult, no. 17: Mead Johnson Symposium on Perinatal and Developmental Medicine. Evansville, IL, pp 17-29

16. Cremer JE, Cunningham VJ, Partridge WM, Braun LD, Oldendorf WH 1979 Kinetics of blood-brain barrier transport of pyruvate, lactate and glucose in suckling, weanling and adult rats. J Neurochem 33:439-445

17. Laptook AR, Stonestreet BS, Oh W 1983 Brain blood flow and $\mathrm{O}_{2}$ delivery during hemorrhagic hypotension in the piglet. Pediatr Res 17:77-80

18. Tofts PS, Cady EB, Delpy DT, Costello AM De L, Hope PL, Reynolds EOR, Wilke DR, Gould SJ, Edwards D 1984 Surface coil NMR spectroscopy of brain. Lancet $2: 459$

19. Heymann MA, Payne BD, Hoffman JIE, Rudolph AM 1977 Blood flow measurements with radionuclide-labelled particles. Prog Cardiovasc Dis 20:55-79

20. Corbett RJT, Laptook AR, Nunnally RL The use of the chemical shift of the phosphomonoester P-31 magnetic resonance peak for the determination of intracellular $\mathrm{pH}$ in the brains of neonates. Neurology 37:1771-1779

21. Norwood WI, Ingwall JS, Norwood CR, Fossel ET 1983 Developmental changes of creatine kinase metabolism in rat brain. Am J Physiol 244:C205210

22. Welsh FA, Ginsberg MD, Rieder W, Budd WW 1978 Diffuse cerebral ischemia in the cat: II. Regional metabolites during severe ischemica and recirculation. Ann Neurol 3:493-501

23. Welsh FA, Greenberg JH, Jones SC, Ginsberg MD, Reivich M 1980 Correlation between glucose utilization and metabolite levels during focal ischemia in cat brain. Stroke 11:79-84

24. Levy DE, Duffy TE 1977 Cerebral energy metabolism during transient ischemia and recovery in the gerbil. J Neurochem 28:63-70

25. Ljunggren B, Schutz H, Siesjo BK 1974 Changes in energy state and acid-base parameters of the rat brain during complete compression ischemia. Brain Res 73:277-289

26. Rehncrona S, Rosen I, Siesjo BK 1981 Brain lactic acidosis and ischemic cel damage: I. Biochemistry and neurophysiology. J Cereb Blood Flow Metab 1:297-311

27. Smith ML, Von Hanwehr R, Siesjo BK 1986 Changes in extra- and intracellular $\mathrm{pH}$ in the brain during and following ischemia in hyperglycemic and in moderately hypoglycemic rats. J Cereb Blood Flow Metab 6:574-583

28. Zierler KL 1961 Theory of the use of arteriovenous concentration differences for measuring metabolism in steady and non-steady states. J Clin Invest 40:2111-2125

29. Abel MS, McCandless DW 1982 Metabolis profile of hippocampal regions after bilateral ischemia and recovery. Neurochem Res 7:789-797

30. Ljunggren B, Ratcheson RA, Siesjo BK 1974 Cerebral metabolic state following complete compression ischemia. Brain Res 73:291-307

31. Steen PA, Milde JH, Michenfelder JD 1978 Cerebral metabolic and vascular effects of barbituate therapy following complete global ischemia. J Neurochem 31:1317-1324

32. Younkin DP, Wagerle LC, Delivoria-Papadopoulos M, Maris J, Rose G, Chance B 1984 Effects of graded hypoxia on cerebral phosphate potential in newborn lambs: a critical bioenergetic level. Pediatr Res 18:303A(abstr)

33. Bessman SP, Geiger PJ 1981 Transport of energy in muscle: the phosphorylcreatine shuttle. Science 211:488-452

34. Delivoria-Papadopoulos M, Wagerle LC, Goplerud JM, Younkin DP, Maris J, Chance B 1985 Carbon monoxide effect on brain oxidative metabolism in newborn piglets. Pediatr Res 19:339A(abstr)

35. Gonzalez-Mendez R, McNeill A, Gregory GA, Wall SD, Gooding CA, Litt L James TL 1985 Effects of hypoxic hypoxia on cerebral phosphate metabolites and $\mathrm{pH}$ in the anesthetized infant rabbit. J Cereb Blood Flow Metab 5:512516

36. Wagerle LC, Delivoria-Papadopoulos M, Younkin DP, Chance B, Maris J 1985 Cerebral bioenergetic reserve and blood flow compensation in hypoxic newborn lambs. Pediatr Res 19:370A(abstr)

37. Hilberman M, Subramanian VH, Haselgrove J, Cone JB, Egan JW, Gyulai L Chance B 1984 In vivo time-resolved brain phosphorus nuclear magnetic resonance. J Cereb Blood Flow Metab 4:334-342 